\title{
PHYSICOCHEMICAL PROPERTIES OF PRE- TREATED CUTTLEBONE POWDER AND ITS POTENTIAL AS AN ALTERNATIVE CALCIUM SOURCE
}

\section{YANG WEN HUEY}

UNIVERSITI SAINS MALAYSIA

JULY 2020 

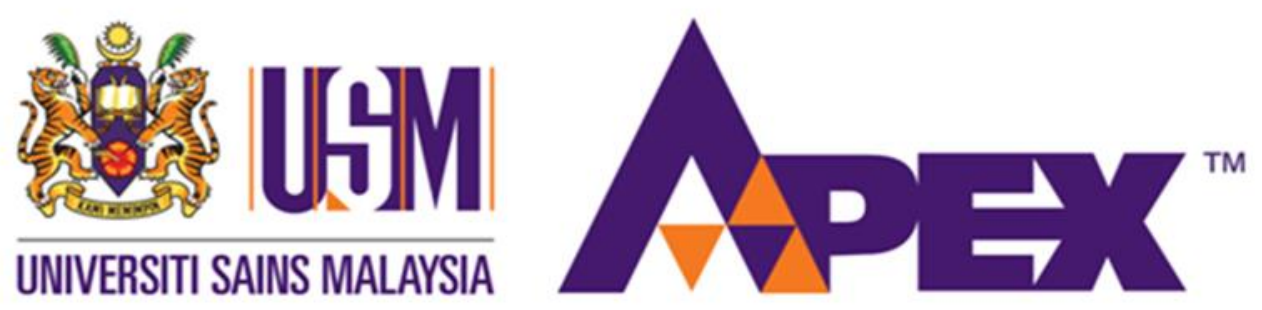

\section{PUSAT PENGAJIAN TEKNOLOGI INDUSTRI UNIVERSITI SAINS MALAYSIA}

\section{BORANG PENYERAHAN DISERTASI MUTAKHIR \\ SATU (1) NASKAH}

Nama penyelia: Dr. Rabeta Mohd Salleh

Bahagian: Teknologi makanan

Saya telah menyemak semua pembetulan/pindaan yang dilaksanakan oleh

Encik/Puan/Cik Yang Wen Huey

mengenai disertasinya sebagaimana yang dipersetujui oleh Panel Pemeriksa di Viva Voce-nya.

2. Saya ingin mengesahkan bahawa saya berpuashati dengan pembetulan/pindaan yang dilaksanakan oleh calon.

Sekian, terima kasih.

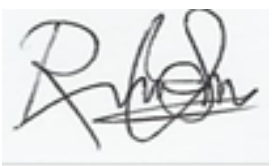

DR. RABETA BT. MOI'D SALLEH

FOOD TECHNOLOGY DIVISION

SCHOOL OF INDUSTRIAL TECHNOLOGY

USM 11800 MINDEN, PENANG

$2 / 8 / 2020$

(Tandatangan dan cop)

Tarikh 


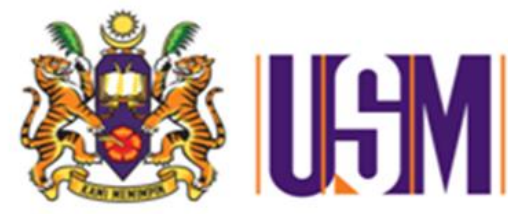

UNIVERSITI SAINS MALAYSIA

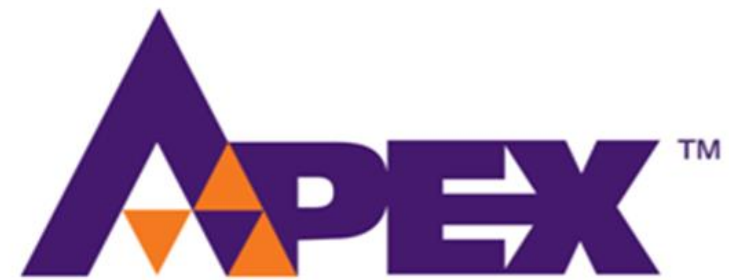

\section{PHYSICOCHEMICAL PROPERTIES OF PRE- TREATED CUTTLEBONE POWDER AND ITS POTENTIAL AS AN ALTERNATIVE CALCIUM SOURCE}

By

\section{YANG WEN HUEY}

A dissertation submitted in partial fulfilment of the requirements for the degree of Bachelor of Technology (B. Tech) in the field of Food Technology

School of Industrial Technology

Universiti Sains Malaysia

July 2020 


\section{DECLARATION BY AUTHOR}

This dissertation is composed of my original work and contains no material previously published or written by another person except where due reference has been made in the text. The content of my dissertation is the result of work I have carried out since the commencement of my research project and does not include a substantial part of work that has been submitted to qualify for the award of any other degree or diploma in any university or other tertiary institution.

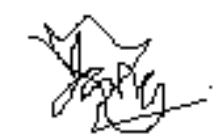

Yang Wen Huey

July 2020 


\section{ACKNOWLEDGEMENTS}

First and foremost, I would like to express my sincere appreciation and gratitude to my final year project supervisor, Dr. Rabeta Mohd Salleh for her guidance and advice throughout the journey of this project. Apart from that, I also appreciate her for willing to spend her valuable time to solve the problems that I faced in this research. Without her dedication, this thesis would not be possible.

Besides, special thanks to all the lab assistants for their guidance in using the instruments and facilities throughout my research study. My biggest gratitude to all the postgraduate students and my course mates, who always willing to lend me a helping hand throughout this project.

Last but not least, I am not forgetting to thank my supportive family for their moral support and invaluable encouragement throughout this project.

Yang Wen Huey

July 2020 
TABLE OF CONTENT

DECLARATION NY AUTHOR

Page

ACKNOWLEDGEMENTS

iii

TABLE OF CONTENT

iv-vii

LISTS OF TABLES

viii

LISTS OF FIGURES

ix

LIST OF ABBREVIATIONS

$\mathrm{X}$

ABSTRAK

xi

ABSTRACT

xii

CHAPTER 1 INTRODUCTION

1.1 Research Background

1.2 Rationale of the Study

1.3 Objective

1.3.1 Main Objective

1.3.2 Specific Objectives

CHAPTER 2 LITERATURE REVIEW

2.1 Cuttlefish

2.2 Cuttlebone

2.3 Medical Benefits of Cuttlebone

2.4 Proximate Analysis of Cuttlebone

2.5 Mineral Content of Cuttlebone 
2.6 Bioactive Compounds

2.6.1 Phenol

2.7 Functional Properties of Food

2.7.5 Water Solubility

\section{CHAPTER 3 METHODOLOGY}

3.1 Materials

3.2 Overall Experimental Design

3.3 Cuttlebone Powder (CBP) Preparation 26

3.4 Cuttlebone Pre-treatment

3.5 Chemical Properties

3.5.1 Proximate Analysis 
3.5.2 Mineral Content 31

3.5.2.1 Sample Digestion 31

3.5.2.2 Preparation of $\mathrm{Ca}, \mathrm{Na}, \mathrm{Mg}, \mathrm{K}$ and Fe Standard Solutions

3.5.2.3 Mineral Content Analysis

3.5.3 Sample Extraction

3.5.4 Qualitative Analysis of Bioactive Compounds

3.5.4.1 Test for Phenol

3.5.4.2 Test for Flavonoids

3.5.4.3 Test for Tannins

3.5.4.4 Test for Alkaloids

3.5.4.5 Test for Glycosides

3.6 Physical Properties

3.6.1 Colour Determination

3.6.2 Bulk density and tapped density

3.6.2.1 Aerated bulk density

3.6.2.2 Tapped density

3.6.2.3 Flowability

3.6.3 Water and Oil Holding Capacity

3.6.3.1 Water Holding Capacity

3.6.3.2 Oil Holding Capacity

3.6.4 Water Solubility

3.7 Statistical Analysis 
4.1 Chemical Properties

4.1.1 Proximate Analysis

$39-45$

4.1.2 Qualitative Analysis of Bioactive Compounds

4.1.3 Minerals Determination

$49-54$

4.2 Physical Properties

4.2.1 Colour Measurement

4.2.2 Bulk Density

$58-60$

4.2.3 Water and Oil Holding Capacity

$60-63$

4.2.4 Water Solubility

$63-65$

CHAPTER 5 CONCLUSION AND RECOMMENDATIONS

5.1 Conclusion

$66-67$

5.2 Recommendations

67

REFERENCES

69-82

APPENDIX

$83-96$ 


\section{LISTS OF TABLES}

Page

Table 2.1 Proximate composition and chitin contents of cuttlebone from cuttlefish caught from Korea and India

Minerals content in cuttlebone from cuttlefish caught from

Table 2.2 Korea and India

Flowability characteristics, Carr index (CI) and Hausner ratio $\left(\mathrm{H}_{\mathrm{R}}\right)$ of powder

Table 3.1 Specification for Carr Index (CI) and Hausner ratio $\left(\mathrm{H}_{\mathrm{R}}\right)$

Proximate composition of cuttlebone powder (CBP) pre-

Table 4.1 treated with distilled water, $1 \%$ acetic acid, $2 \%$ sodium hydroxide and raw $\mathrm{CBP}^{1}$

Qualitative analysis of bioactive compounds of

Table 4.2 polysaccharide extracted from raw cuttlebone powder with $45-46$ ethylenediaminetetraacetic acid (EDTA).

Minerals content of cuttlebone powder (CBP) pre-treated

Table 4.3 with distilled water, $1 \%$ acetic acid, $2 \%$ sodium hydroxide and raw CBP from Korea and India

Colour measurement of cuttlebone powder (CBP) pre-treated

Table 4.4 with distilled water, $1 \%$ acetic acid and $2 \%$ sodium hydroxide.

Aerated and tapped density, Carr index (CI), Hausner ratio

Table $4.5 \quad\left(\mathrm{H}_{\mathrm{R}}\right)$ and flowability properties of cuttlebone powder (CBP) pre-treated with distilled water, $1 \%$ acetic acid and $2 \%$ sodium hydroxide.

Water holding capacity (WHC) and oil holding capacity

Table 4.6 (OHC) of cuttlebone powder (CBP) pre-treated with distilled 60 water, $1 \%$ acetic acid and $2 \%$ sodium hydroxide.

Water solubility of cuttlebone powder (CBP) pre-treated

Table 4.7 with distilled water, $1 \%$ acetic acid and $2 \%$ sodium hydroxide. 


\section{LISTS OF FIGURES}

\section{Page}

$\begin{array}{lll}\text { Figure 2.1 Dorsal shield of cuttlebone } & 7\end{array}$

$\begin{array}{lll}\text { Figure 2.2 Lamellar matrix of cuttlebone } & 7\end{array}$

$\begin{array}{lll}\text { Figure 3.1 Overview of experimental design } & 24\end{array}$

Figure 4.1 Observation of phenol test 45

Figure 4.2 Observation of flavonoid test 45

Figure 4.3 Observation of alkaloid test 45

Figure 4.4 Observation of glycoside test 46

Figure 4.5 Observation of tannins test 46 


\section{LIST OF ABBREVIATIONS}

$\begin{array}{ll}\text { CBP } & \text { Cuttlebone powder } \\ \text { CBP1 } & \text { Cuttlebone powder pre-treated with distilled water } \\ \text { CBP2 } & \text { Cuttlebone powder pre-treated with } 1 \% \text { acetic acid solution } \\ \text { CBP3 } & \text { Cuttlebone powder pre-treated with } 2 \% \text { sodium hydroxide solution } \\ \mathrm{Ca} & \text { Calcium } \\ \text { DPPH } & \text { 1,1-diphenyl-2-picrylhydrazylradicals } \\ \text { Fe } & \text { Iron } \\ \text { FAO } & \text { Food and Agricultural Organization } \\ \text { K } & \text { Potassium } \\ \text { Mg } & \text { Magnesium } \\ \text { MOH } & \text { Ministry of Health Malaysia } \\ \text { Na } & \text { Sodium } \\ \text { NaOH } & \text { Sodium hydroxide } \\ \text { WHC } & \text { Water Holding Capacity } \\ \text { WHO } & \text { World Health Organization } \\ \text { OHC } & \text { Oil Holding Capacity } \\ & \end{array}$




\title{
SIFAT FIZIKO KIMIA SERBUK TULANG SOTONG KATAK YANG DIRAWAT DAN POTENSINYA SEBAGAI SUMBER KALSIUM ALTERNATIF
}

\begin{abstract}
ABSTRAK
Kajian ini bertujuan untuk mengkaji potensi serbuk tulang sotong katak yang dirawat sebagai sumber kalsium alternatif dengan menilai sifat-sifat fizikokimia serbuk tulang sotong katak yang dirawat terlebih dahulu dengan air suling (CBP1), $1 \%$ asid asetik (CBP2) dan larutan natrium hidroksida 2\% (CBP3). Pra-rawatan digunakan untuk mengekstrak abu dengan membuang bahan organik seperti protein dan lemak. Sifat-sifat kimia seperti komposisi proksimat, kandungan mineral dan sebatian bioaktif, juga sifat-sifat fizikal, seperti warna, ketumpatan pukal, sifat aliran, kapasiti penahan air dan minyak dan kelarutan air, juga ditentukan. Analisis proksimat menunjukkan abu adalah komponen utama yang terdapat dalam kesemua sampel. Analisis kualitatif sebatian bioaktif yang dijalankan ke atas ekstrak polisakarida tulang sotong katak, dan kehadiran fenol, flavonoid, alkaloid dan glikosida dikesan. Tiada kehadiran tanin dalam tulang sotong katak. Analisis mineral menunjukkan serbuk tulang sotong katak yang dirawat kaya dengan kalsium, dan berpotensi dianggap sebagai sumber kalsium dalam produk makanan atau suplemen kalsium. Kandungan mineral semua sampel meningkat mengikut urutan besi <kalium <magnesium < natrium <kalsium. Didapati tiada perbezaan yang signifikan $(\mathrm{p}>0.05)$ pada keputihan dan kemerahan semua sampel, tetapi kekuningan CBP1 jauh lebih tinggi berbanding CBP2 dan CBP3. Ketumpatan pukal CBP2 lebih rendah secara signifikan $(\mathrm{p}<0.05)$ berbanding CBP1 dan $\mathrm{CBP} 3$, sementara daya tahan air $\mathrm{CBP} 1$ lebih tinggi secara signifikan $(\mathrm{p}<0.05)$ berbanding CBP2 dan CBP3. Didapati tiada perbezaan yang signifikan ( $>>0.05)$ pada daya tahan minyak dan kelarutan air kesemua sampel. Ketumpatan pukal yang relatif tinggi dan daya tahan air dan minyak serbuk tulang sotong katak yang dirawat menunjukkan potensinya sebagai bahan makanan berfungsi.
\end{abstract}




\title{
PHYSICOCHEMICAL PROPERTIES OF PRE-TREATED CUTTLEBONE POWDER AND ITS POTENTIAL AS AN ALTERNATIVE CALCIUM SOURCE
}

\begin{abstract}
This study was aimed to investigate the potential use of pre-treated cuttlebone powder (CBP) as an alternative calcium source by evaluating the physicochemical properties of CBP pre-treated with distilled water (CBP1), $1 \%$ acetic acid (CBP2) and $2 \%$ sodium hydroxide $(\mathrm{NaOH})$ solutions $(\mathrm{CBP} 3)$. Pre-treatments were used to extract ash and degrade the organic matters such as proteins and fats. The chemical properties including proximate composition, mineral contents and bioactive compounds as well as physical properties, including colour, bulk density, flowability, water and oil holding capacities and water solubility, of the samples were then determined. Proximate analysis revealed ash as the major component of all samples. Qualitative analysis of bioactive compounds was conducted on polysaccharides extracted from cuttlebone, and the presence of phenols, flavonoids, alkaloids and glycosides were detected. Tannins appeared to be absent in cuttlebones. Mineral analysis indicated that pre-treated CBP was rich in calcium, which means the material may be considered as a potential calcium source for food products or calcium supplements. The mineral contents of all samples increased in the order of iron $<$ potassium $<$ magnesium $<$ sodium $<$ calcium. No significant difference $(p>0.05)$ in the whiteness and redness of all samples was observed, but the yellowness of CBP1 was significantly greater than those of CBP2 and CBP3. The bulk density of CBP2 was significantly lower $(\mathrm{p}<0.05)$ than those of CBP1 and CBP3, and the water holding capacity (WHC) of CBP1 was significantly higher $(\mathrm{p}<0.05)$ than those of $\mathrm{CBP} 2$ and CBP3. No significant differences ( $>0.05)$ in oil holding capacity $(\mathrm{OHC})$ and water solubility were observed amongst the samples. The high bulk density, water and oil holding capacities of pre-treated CBP demonstrated its potential use as a functional food ingredient.
\end{abstract}

